ISSN 0258-7122

Bangladesh J. Agril. Res. 36(1) : 271-278, March 2011

\title{
EFFECT OF SOWING TIME AND PLANT SPACING ON THE YIELD AND YIELD ATTRIBUTES OF SWEET PEPPER (Capsicum annuum)
}

\author{
M. S. ALAM ${ }^{1}$, S. R. SAHA ${ }^{2}$, M. A. SALAM ${ }^{3}$ \\ M. S. ALAM ${ }^{4}$ AND M. K. ALAM ${ }^{5}$
}

\begin{abstract}
An experiment was carried out at the Olericulture field of Horticulture Research Centre of BARJ, Joydebpur, Gazipur during September 2006 to April 2007 to investigate yield and yield attributes of sweet pepper as influenced by plant spacing and sowing time. There were altogether 21 treatments comprising seven sowing dates viz. 1 September, 15 September, 1 October, 15 October, 30 October, 15 November, 30 November and three spacings viz. $50 \times 50 \mathrm{~cm}, 50 \times 40$ $\mathrm{cm}$, and $50 \times 30 \mathrm{~cm}$. The experiment was laid out in a Randomized Complete Block Design (factorial) with three replications. The results of the experiment showed that majority of the yield and yield components significantly varied with variation of spacing and sowing time. Only number of fruits per plant and fruit yield per plant resulted significantly higher which reflected higher yield for 1 October sowing. The number of branches per plant, number of fruits per plant, fruit length, individual fruit weight, yield per plant were found significantly increased with the increasing plant spacings but other parameters were found to be significantly increased with the decreasing plant spacing. The combined effect of sowing date and plant spacing also had significant effect on different growth and yield parameters and yield. The highest yield (19.36 t/ha) of fruit was recorded from the earlier sowing (1 October) with the closest spacing $(50 \times 30$ $\mathrm{cm})$. But reasonable yield could be obtained up to 30 October with same spacing.
\end{abstract}

Keywords: Sowing time and plant spacing, yield and yield attributes, sweet pepper.

\section{Introduction}

Sweet pepper (Capsicum annuum var. grossum L.) belongs to the family solanaceae under the genus capsicum. Sweet pepper is native to Tropical South America. Especially Brazil is thought to be the original home of peppers (Shoemaker and Teskey, 1955). It is now widely cultivated in Central and South America, Peru, Bolivia, Costa Rica, Mexico, in almost all the European countries, Honkong, and India. The sweet pepper is relatively non-pungent with thick flesh and it is the world's second most important vegetables after tomato (AVRDC, 1989). Sweet pepper is used either green or red, and may be eaten as cooked or raw vegetable, as well as in salad. It is used for piciking in brine,

\footnotetext{
${ }^{1}$ Scientific Officer, Horticulture Research Centre (HRC), Bangladesh Agricultural Research Institute (BARI), Gazipur, ${ }^{2}$ Principal Scientific Officer, HRC, BARI, Gazipur, ${ }^{3}$ Senior Scientific Officer, HRC, BARI, Gazipur, ${ }^{4}$ Scientific Officer, Tuber Crops Research Centre (TCRC), BARI, Gazipur, ${ }^{5}$ Assistant Scientific Officer, Breeding Division, BARI, Gazipur, Bangladesh.
} 
baking and stuffing. Sweet pepper has a little energy value. But the nutritive value of sweet pepper is high as it contains $1.29 \mathrm{mg}$ protein, $11 \mathrm{mg}$ calcium, 870 I.U vitamin-A, $175 \mathrm{mg}$ ascorbic acid, $0.06 \mathrm{mg}$ thiamine, $0.03 \mathrm{mg}$ riboflavin and $0.55 \mathrm{mg}$ niacin per $100 \mathrm{~g}$ edible fruit (Joshi and Singh, 1975). The vitamin C content was found as high as $321 \mathrm{mg}$.

Meanwhile, Macrae et al. (1993) stated that green peppers, with a $\beta$-carotene equivalent to $180 \mathrm{~g}$ per $100 \mathrm{~g}$ contain approximately as much carotene as spinach. Sweet pepper is a minor vegetable in Bangladesh and its production statistics is not available (Hasanuzzaman, 1999). A small-scale cultivation is found in peri-urban areas primarily for the supply to some city markets in Bangladesh. The crop has got high export potentiality. Considering its high nutritive value and export potentiality, it is imperative to take attempts for its successful cultivation in the country. Successful cultivation of any crop depends on several factors. Sowing or planting time and plant spacing are of the important aspects for production system of different crops. Optimum sowing or planting time and plant spacing ensures proper growth and development of plant resulting maximum yield of crop and economic use of land. Yield of sweet pepper has been reported to be dependent on the number of plants accommodated per unit area of land but there are very few reports regarding sowing or planting time and spacing to cultivate the crop under the agro-climatic conditions of Bangladesh. Considering the above facts, the present experiment was undertaken to find out the ortimum sowing time and spacing for higher yield of sweet pepper in Bangladesh.

\section{Materials and Method}

The experiment was conducted at HRC, BARI, Gazipur during September 2006 to April 2007 and set up in a randomized complete block design (factorial) with three replications. There were seven sowing dates viz. 1 September, 15 September, 1 October, 15 October, 1 November, 15 November, and 30 November and three spacings, namely $50 \times 50 \mathrm{~cm}, 50 \times 40 \mathrm{~cm}$, and $50 \times 30 \mathrm{~cm}$. Thus, there were altogether 21 treatment combinations in the experiment. Thirty days old seedlings were transplanted in the main field in each of the sowings. The crop was fertilized with cowdung @ 10 t/ha and Urea, TSP, MoP, Gypsum and ZnO @ 217, 333, 200, 111, and 5 kg/ha, respectively. Half of the quantity of cowdung was applied during final land preparation. The remaining half of the cowdung. the entire quantity of TSP, ZnO, Gypsum and one-third each of Urea and MoP were applied during pit preparation. The rest of Urea and MoP were applied in two equal splits at 25 and 50 days after transplanting in the main field. Irrigation along with other intercultural operations were done as and when needed Data on different yield contributing characters were recorded and analyzed statistically. The mean data were separated by DMRT for interpretation of the results. 


\section{Results and Discussion}

\section{Effects of sowing time}

Sowing time significantly influenced the plant height of sweet pepper. Plant height ranged from $37.62 \mathrm{~cm}$ to $46.32 \mathrm{~cm}$ at final harvest. The tallest plant (46.32 $\mathrm{cm}$ ) was found in 1 October sowing but at par to 1 September sowing whereas, the shortest plant was found in 30 November sowing. The effect of sowing dates was significantly pronounced on the number of branches per plant. The maximum branches (5.20) were produced in 1 September and 1 October sowings followed by 15 September, 15 October, and 30 October sowings which were statistically identical. The minimum branches (4.30) were produced in 30 November sowing but statistically at par to 15 November sowing. It was observed that 1 October sowing produced the maximum number of fruits per plant (8.69) and 30 November produced the minimum (Table 1). Significant variation was observed on fruit size at different sowing dates in respect of length and diameter. September 1 sowing gave the highest fruit length $(6.54 \mathrm{~cm})$ where the diameter was measured the lowest $(5.32 \mathrm{~cm})$. The lowest length of fruit $(5.25$ $\mathrm{cm})$ was found in 30 October sowing and 15 October sowing gave the maximum diameter $(6.20 \mathrm{~cm})$, which was statistically identical to other date of October sowing. Influence of sowing time on individual fruit weight was found significant where the highest individual weight of fruit $(49.26 \mathrm{~g})$ was produced from 15 September sowing and the lowest $(37.57 \mathrm{~g})$ was produced by the plant sown on 30 November. Considerable diversity was visible on yield per plant where the highest fruit yield per plant $(326.91 \mathrm{~g}$ ) was obtained from 1 October sowing which was significantly different from other sowings and the minimum from 30 November sowing (Table 1). Fruit yield/ha, of sweet pepper differed significantly due to sowing time and it varied from 7.19 to 16.33 t/ha. The highest yield was $16.33 \mathrm{t} / \mathrm{ha}$ as observed in 1 October sowing due to higher fruits/plant and fruit yield/plant. Fruit yield was reduced considerably after October sowing and lowest yield was recorded from 30 November sowing.

\section{Effects of spacing}

Effects of plant spacing was found to be significant on plant height at final harvest (Table 2). The closest spacing $(50 \times 30 \mathrm{~cm})$ produced the tallest $(45.14$ $\mathrm{cm})$ plant and the shortest plants were obtained from the wider spacing The results of the present study for this character are in agreement with the findings of Maya et al. (1997) who stated that plant height of sweet pepper was significantly increased with closer spacing. Viloria et al. (1998) and Manchanda et al. (1988) also expressed similar opinion on plant height of sweet pepper. Number of branches per plant differed significantly by different spacings (Table 2). The highest number of branches per plant (5.63) was recorded from wider spacing $(50 \times 50 \mathrm{~cm})$ and the closest spacing $(50 \times 30 \mathrm{~cm})$ gave the lowest number of branches (4.12). The plant spacing influenced significantly at $1 \%$ level of 
Table 1. Effect of sowing time yield and yield contributing characters of sweet pepper.

\begin{tabular}{|c|c|c|c|c|c|c|c|c|c|}
\hline $\begin{array}{l}\text { Sowing } \\
\text { time }\end{array}$ & $\begin{array}{c}\text { Plant } \\
\text { height }(\mathrm{cm})\end{array}$ & $\begin{array}{c}\text { No. of } \\
\text { branches/ } \\
\text { plant }\end{array}$ & $\begin{array}{c}\text { Days to } \\
50 \% \\
\text { flowering }\end{array}$ & $\begin{array}{l}\text { No. of } \\
\text { fruits/ } \\
\text { plant }\end{array}$ & $\begin{array}{l}\text { Fruit } \\
\text { length } \\
(\mathrm{cm})\end{array}$ & $\begin{array}{c}\text { Fruit } \\
\text { breadth } \\
(\mathrm{cm})\end{array}$ & $\begin{array}{l}\text { Individual } \\
\text { fruit weight } \\
\text { (g) }\end{array}$ & $\begin{array}{c}\text { Fruit } \\
\text { yield/ } \\
\text { plant (g) }\end{array}$ & $\begin{array}{l}\text { Fruit } \\
\text { yield } \\
\text { (t/ha) }\end{array}$ \\
\hline 1 Sept. & $43.92 \mathrm{ab}$ & $5.20 \mathrm{a}$ & $74.78 b$ & $5.13 c$ & $6.54 a$ & $5.32 \mathrm{c}$ & $41.32 \mathrm{c}$ & $218.95 d$ & $10.96 \mathrm{~d}$ \\
\hline 15 Sept. & $41.71 b c$ & $4.78 \mathrm{ab}$ & $69.10 \mathrm{c}$ & $4.99 c$ & $5.99 \mathrm{~b}$ & $5.49 b c$ & $49.26 \mathrm{a}$ & $246.03 c$ & $12.49 \mathrm{c}$ \\
\hline 1 Oct. & $46.32 \mathrm{a}$ & $5.20 \mathrm{a}$ & $75.06 \mathrm{~b}$ & $8.69 *$ & $5.78 b$ & $6.12 \mathrm{a}$ & $41.28 \mathrm{c}$ & $326.91 \mathrm{a}$ & $16.33 \mathrm{a}$ \\
\hline 15 Oct. & $43.70 \mathrm{~b}$ & $5.15 \mathrm{a}$ & $77.00 \mathrm{~b}$ & $6.41 b$ & $5.44 \mathrm{c}$ & $6.20 \mathrm{a}$ & $44.75 b$ & $287.64 b$ & $14.18 \mathrm{~b}$ \\
\hline 30 Oct. & $40.89 \mathrm{c}$ & $4.98 \mathrm{a}$ & $78.55 b$ & $4.66 \mathrm{~cd}$ & $5.25 \mathrm{c}$ & $6.13 \mathrm{a}$ & $44.47 b$ & $225.20 d$ & $11.20 \mathrm{~d}$ \\
\hline 15 Nov. & $38.32 \mathrm{~d}$ & $4.32 b$ & $85.07 \mathrm{a}$ & 4. $17 \mathrm{~d}$ & $5.47 \mathrm{c}$ & $5.79 b$ & $40.78 \mathrm{c}$ & $185.31 \mathrm{e}$ & $9.08 \mathrm{e}$ \\
\hline 30 Nov. & $37.62 d$ & $4.30 \mathrm{~b}$ & $84.22 \mathrm{a}$ & $3.48 \mathrm{e}$ & $5.38 \mathrm{c}$ & $5.67 \mathrm{~b}$ & $37.57 \mathrm{~d}$ & $146.64 f$ & $7.19 \mathrm{f}$ \\
\hline $\begin{array}{l}\text { Level of } \\
\text { significance }\end{array}$ & $* *$ & $* *$ & $* *$ & $* *$ & $* *$ & $* *$ & $* *$ & $* *$ & $* *$ \\
\hline
\end{tabular}

Means in a column followed by the same letters are not significantly different at $1 \%$ level of probability as per DMRT

** Significant at $1 \%$ level of probability.

Table 2. Effect of spacing on yield and yield contributing characters of sweet pepper.

\begin{tabular}{|c|c|c|c|c|c|c|c|c|c|}
\hline Spacing $\left(\mathrm{cm}^{2}\right)$ & $\begin{array}{l}\text { Plant } \\
\text { height } \\
(\mathrm{cm})\end{array}$ & $\begin{array}{l}\text { No. of } \\
\text { branches } \\
\text { plant }\end{array}$ & $\begin{array}{c}\text { Days to } 50 \% \\
\text { flowering }\end{array}$ & $\begin{array}{l}\text { No. of } \\
\text { fruits } \\
\text { /plant }\end{array}$ & $\begin{array}{l}\text { Fruit } \\
\text { length } \\
(\mathrm{cm})\end{array}$ & $\begin{array}{l}\text { Fruit } \\
\text { breadth } \\
(\mathrm{cm}\end{array}$ & $\begin{array}{l}\text { Individual } \\
\text { fruit weight } \\
\text { (g) }\end{array}$ & $\begin{array}{l}\text { Fruit } \\
\text { yield } \\
\text { /plant }\end{array}$ & $\begin{array}{c}\text { Fruit } \\
\text { yield (t/ha) }\end{array}$ \\
\hline $50 \times 50$ & $39.54 b$ & $5.63 \mathrm{a}$ & $75.14 b$ & $6.08 *$ & $5.97 \mathrm{a}$ & $5.64 b$ & $44.84 \mathrm{a}$ & $271.12 \mathrm{a}$ & $10.99 b$ \\
\hline $50 \times 40$ & $40.67 b$ & $4.79 b$ & $78.25 \mathrm{a}$ & $5.37 \mathrm{~b}$ & $5.67 \mathrm{~b}$ & $5.94 \mathrm{a}$ & $42.65 \mathrm{~b}$ & $238.50 \mathrm{~b}$ & $11.13 b$ \\
\hline $50 \times 30$ & $45.14 \mathrm{a}$ & 4. $12 \mathrm{c}$ & $79.65 a$ & $4.63 c$ & $5.45 \mathrm{c}$ & $5.88 \mathrm{a}$ & $40.84 \mathrm{c}$ & $191.73 c$ & $12.78 \mathrm{a}$ \\
\hline
\end{tabular}

significance

Means in a column followed by the same letters are not significantly different at $1 \%$ level of probability as per DMRT

** Significant at $1 \%$ level of probability. 
probability as to the days to $50 \%$ flowering. Flowering occurred earlier ( 75 days) when plants were grown at wider spacing $(50 \times 50 \mathrm{~cm})$ but late flowering $(78.80$ days) occurred in plants with closer spacing. The result is in consistent with that of Srivastava (1996) who reported that days to $50 \%$ flowering decreased with increasing spacing. Marked variation was observed on the number of fruits per plant under different plant spacings, which ranged from 4.63 to 6.08. It was noted that wider spacing produced significantly highest (6.08) number of fruits per plant. Mishriky and Alphose (1994) also supported these findings. The highest $(5.97 \mathrm{~cm})$ and the lowest $(5.45 \mathrm{~cm})$ fruit length were measured from the spacings $50 \times 50 \mathrm{~cm}$ and $50 \times 30 \mathrm{~cm}$, respectively, where fruit breadth was measured the highest $(5.94 \mathrm{~cm})$ and the lowest $(5.64 \mathrm{~cm})$ from the spacings $50 \times 40 \mathrm{~cm}$ and $50 \times 50 \mathrm{~cm}$, respectively. Manchanda et al. (1988) reported that the number of fruits per plant and fruit length increased with decreasing plant density, which is in agreement with the present study. Diversity was observed due to different levels of spacing on the parameters individual fruit weight as well as yield per plant (Table 2). The highest individual fruit weight $(44.84 \mathrm{~g})$ consequently the highest yield per plant $(27.12 \mathrm{~g})$ were found at the widest spacing $(50 \times 50 \mathrm{~cm})$, while the lowest individual fruit weight was found at the closest $(50 \times 30 \mathrm{~cm})$ spacing. Verheij and Verwer (1973) also found the similar trend who reported that the individual fruit weight declined with increased plant density. Plant spacing had significant effect on yield per hectare (Table 2). The closest spacing $(50 \times 30 \mathrm{~cm})$ produced the maximum yield of fruit $(12.78 \mathrm{t} / \mathrm{ha})$ and the widest $(50 \times 50 \mathrm{~cm})$ spacing showed the minimum $(10.99 \mathrm{t} / \mathrm{ha})$. Though fruits/plant, fruit weight, and yield/plant were lower in closer spacing but due to higher plants $/ \mathrm{m}^{2}$ resulted high yield from closer spacing $(50 \times 30 \mathrm{~cm})$. The result of the present experiment is in agreement with the findings of Manchanda et al. (1988), Ramachandran and Subbiah (1981). Mishriky and Alphons (1994) also obtained the highest yield (22.9 t/ha) from closer spacing.

\section{Combined effect of sowing time and spacing}

The combined effect of sowing date and spacing on plant height at final harvest was statistically significant (Table 3). The maximum plant height $(47.92 \mathrm{~cm}$ was obtained from I October sowing with spacing $(50 \times 30 \mathrm{~cm})$ and the shortest $(34.62$ $\mathrm{cm}$ ) plant was found in 15 and 30 November sowings with wider spacing. There

was trend to increased plant height with the decrease of spacing irrespective of sowing date. The combined effect of sowing date and spacing was found to be significant on number of branches per plant. The maximum branches were produced when plants were sown on 15 October followed by 1 October with $50 \times 50 \mathrm{~cm}$ spacing and the minimum branches (3.21) were found in 15 November sowing with $50 \times 30 \mathrm{~cm}$ spacing. Days to $50 \%$ flowering was significantly influenced where late sowing (30 November) took the maximum period (89 days) with the closest spacing $(50 \times 30 \mathrm{~cm})$. Earlier sowing $(1-15$ September) took 
Table 3 Combined effect of planting time and plant spacing on yield and yield contributing characters of sweet pepper.

\begin{tabular}{|c|c|c|c|c|c|c|c|c|c|c|}
\hline \multicolumn{2}{|c|}{ Treatment } & \multirow{2}{*}{$\begin{array}{l}\text { Plant } \\
\text { height } \\
(\mathrm{cm})\end{array}$} & \multirow{2}{*}{$\begin{array}{c}\text { No. of } \\
\text { branches/ } \\
\text { plant }\end{array}$} & \multirow{2}{*}{$\begin{array}{c}\text { Days to } \\
50 \% \\
\text { flowering }\end{array}$} & \multirow{2}{*}{$\begin{array}{l}\text { No. of } \\
\text { fruits/ } \\
\text { plant }\end{array}$} & \multirow{2}{*}{$\begin{array}{l}\text { Fruit } \\
\text { length } \\
(\mathrm{cm})\end{array}$} & \multirow{2}{*}{$\begin{array}{l}\text { Fruit } \\
\text { breadth } \\
(\mathrm{cm})\end{array}$} & \multirow{2}{*}{$\begin{array}{c}\text { Individual } \\
\text { fruit } \\
\text { wt }(\mathrm{g})\end{array}$} & \multirow{2}{*}{$\begin{array}{c}\text { Fruit yield } \\
\text { /plant } \\
\text { (g) }\end{array}$} & \multirow{2}{*}{$\begin{array}{l}\text { Fruit } \\
\text { yield } \\
\text { (t/ha) }\end{array}$} \\
\hline Sowing time & $\begin{array}{l}\text { Spacing } \\
(\mathrm{cm})\end{array}$ & & & & & & & & & \\
\hline \multirow[t]{3}{*}{1 Sept. } & $50 \times 50$ & $41.91 \mathrm{~b}-\mathrm{e}$ & $5.47 \mathrm{ab}$ & $70.33 \mathrm{efg}$ & $5.36 \mathrm{dc}$ & $7.16 \mathrm{a}$ & $5.27 \mathrm{e}$ & $43.30 \mathrm{c}-\mathrm{g}$ & $237.48 \mathrm{de}$ & $9.5 \mathrm{ij}$ \\
\hline & $50 \times 40$ & 42.95 a-e & $5.80 \mathrm{a}$ & $76.00 \mathrm{c}-\mathrm{f}$ & $5.24 \mathrm{de}$ & 6.7lab & $5.24 \mathrm{e}$ & $40.67 \mathrm{e}-\mathrm{i}$ & $228.75 \mathrm{e}$ & $10.67 \mathrm{ghi}$ \\
\hline & $50 \times 30$ & $46 . .90 \mathrm{ab}$ & $4.33 c$ & $78.00 \mathrm{~cd}$ & $4.77 \mathrm{eg}$ & $5.75 \mathrm{de}$ & $5.44 \mathrm{cde}$ & 39.99 ghi & $190.61 \mathrm{fg}$ & $12.70 \mathrm{ef}$ \\
\hline \multirow[t]{3}{*}{15 Sept. } & $50 \times 50$ & $38.78 d-g$ & $5.54 \mathrm{ab}$ & $67.33 \mathrm{~g}$ & 5.91cd & $6.56 \mathrm{bc}$ & 5.4lcde & $51.36 \mathrm{a}$ & $289.80 \mathrm{c}$ & $12.60 \mathrm{ef}$ \\
\hline & $50 \times 40$ & $40.68 \mathrm{c}-\mathrm{f}$ & $4.67 b c$ & $69.30 \mathrm{fg}$ & $4.88 \mathrm{efg}$ & $6.01 \mathrm{de}$ & $5.70 \mathrm{cde}$ & $48.98 \mathrm{ab}$ & $250.67 d$ & I $1.69 f g$ \\
\hline & $50 \times 30$ & $45.66 \mathrm{abc}$ & $4.13 \mathrm{~cd}$ & $70.67 \mathrm{efg}$ & $4.17 \mathrm{f}-\mathrm{i}$ & $5.42 \mathrm{fgh}$ & $5.33 \mathrm{de}$ & $47.43 \mathrm{abc}$ & $197.62 f$ & $13.17 \mathrm{de}$ \\
\hline \multirow[t]{3}{*}{$1 \mathrm{Oct}$} & $50 \times 50$ & $45.37 \mathrm{abc}$ & $6.06 a$ & $79.67 \mathrm{bcd}$ & $10.41 \mathrm{a}$ & $6.22 \mathrm{~cd}$ & $5.67 \mathrm{cde}$ & $46.28 \mathrm{bcd}$ & $388.63 a$ & $14.08 \mathrm{~cd}$ \\
\hline & $50 \times 40$ & $45.66 \mathrm{abc}$ & $4.80 \mathrm{bc}$ & $70.25 \mathrm{efg}$ & $7.83 b$ & $5.61 \mathrm{dfg}$ & $6.0 \mathrm{lbc}$ & $40.35 \mathrm{f}-\mathrm{i}$ & $301.64 c$ & $15.55 b$ \\
\hline & $50 \times 30$ & $47.92 \mathrm{a}$ & $4.73 \mathrm{~cd}$ & $75.25 \mathrm{def}$ & $7.85 b$ & $5.56 \mathrm{efg}$ & $6.68 \mathrm{a}$ & $37.21 \mathrm{i}$ & $290.45 c$ & $19.36 \mathrm{a}$ \\
\hline \multirow[t]{3}{*}{15 Oct. } & $50 \times 50$ & $42.84 b-e$ & $6.11 \mathrm{a}$ & $76.33 \mathrm{c}-\mathrm{f}$ & $7.52 b$ & $5.27 \mathrm{fgh}$ & $5.90 \mathrm{bcd}$ & $46.68 \mathrm{bad}$ & $339.34 b$ & $13.57 d$ \\
\hline & $50 \times 40$ & $43.17 \mathrm{a}-\mathrm{e}$ & $4.63 b c$ & $76.67 \mathrm{cde}$ & $6.33 c$ & $5.37 \mathrm{fgh}$ & $6.36 \mathrm{ab}$ & $45.08 \mathrm{~b}-\mathrm{e}$ & 295.61c & $13.79 \mathrm{de}$ \\
\hline & $50 \times 30$ & $45.10 \mathrm{abc}$ & $4.70 \mathrm{dc}$ & $78.00 \mathrm{~cd}$ & $5.37 \mathrm{de}$ & 5.67ef & $6.36 \mathrm{ab}$ & 42.48 d-h & $227.97 \mathrm{e}$ & $15.19 b c$ \\
\hline \multirow[t]{3}{*}{30 Oct. } & $50 \times 50$ & $38.64 \mathrm{efg}$ & $5.88 \mathrm{a}$ & $74.67 \mathrm{def}$ & 5.0ldef & $5.29 \mathrm{fgh}$ & $5.67 \mathrm{cde}$ & $45.06 \mathrm{~b}-\mathrm{e}$ & $250.84 d$ & 10.03hij \\
\hline & $50 \times 40$ & $39.12 \mathrm{~d}-\mathrm{g}$ & $4.67 \mathrm{bc}$ & $80.33 \mathrm{bcd}$ & $4.83 \mathrm{efg}$ & $5.03 \mathrm{gh}$ & $6.70 \mathrm{a}$ & $44.83 \mathrm{~b}-\mathrm{f}$ & $236.02 \mathrm{de}$ & $11.01 \mathrm{gh}$ \\
\hline & $50 \times 30$ & $44.92 \mathrm{abc}$ & $4.40 c$ & $80.65 \mathrm{bcd}$ & $4.13 \mathrm{f}-\mathrm{i}$ & $5.33 \mathrm{fgh}$ & $6.03 b c$ & $43.53 \mathrm{c}-\mathrm{g}$ & $188.20 \mathrm{fg}$ & $12.55 \mathrm{cf}$ \\
\hline \multirow[t]{3}{*}{15 Nov. } & $50 \times 50$ & $34.62 \mathrm{~g}$ & $5.47 \mathrm{ab}$ & $82.67 \mathrm{abc}$ & $4.62 \mathrm{e}-\mathrm{h}$ & $5.53 \mathrm{def}$ & $5.13 \mathrm{cde}$ & $42.70 \mathrm{~d}-\mathrm{h}$ & $220.81 \mathrm{e}$ & $8.83 \mathrm{j}$ \\
\hline & $50 \times 40$ & $36.73 \mathrm{fg}$ & $4.27 \mathrm{c}$ & $86.54 \mathrm{ab}$ & $4.52 \mathrm{e}-\mathrm{h}$ & $5.47 \mathrm{fgh}$ & $5.82 \mathrm{~b}-\mathrm{e}$ & $41.42 \mathrm{e}-\mathrm{i}$ & $196.41 \mathrm{f}$ & $9.16 \mathrm{j}$ \\
\hline & $50 \times 30$ & $43.62 \mathrm{a}-\mathrm{d}$ & $3.21 \mathrm{e}$ & $86.00 \mathrm{ab}$ & $3.38 \mathrm{ij}$ & $5.40 \mathrm{fgh}$ & $5.82 \mathrm{~b}-\mathrm{e}$ & $38.21 \mathrm{hi}$ & $138.72 \mathrm{i}$ & $9.25 \mathrm{j}$ \\
\hline \multirow[t]{3}{*}{30 Nov. } & $50 \times 50$ & $34.62 \mathrm{~g}$ & $4.87 b c$ & $75.00 \mathrm{def}$ & $3.69 \mathrm{~h}-\mathrm{i}$ & $5.75 \mathrm{def}$ & $5.80 \mathrm{~b}-\mathrm{d}$ & $38.51 \mathrm{hi}$ & $170.97 \mathrm{gh}$ & $6.84 \mathrm{k}$ \\
\hline & $50 \times 40$ & $36.41 \mathrm{fg}$ & $4.67 \mathrm{bc}$ & $88.67 \mathrm{a}$ & $3.98 \mathrm{ghi}$ & $5.37 \mathrm{fgh}$ & $5.13 \mathrm{cde}$ & $37.21 \mathrm{i}$ & $160.42 \mathrm{~h}$ & $7.51 \mathrm{k}$ \\
\hline & $50 \times 30$ & $41.84 \mathrm{cde}$ & $3.37 \mathrm{de}$ & $89.00 \mathrm{a}$ & $2.76 \mathrm{j}$ & $5.00 \mathrm{~h}$ & $5.50 \mathrm{cde}$ & $37.00 \mathrm{i}$ & $108.52 \mathrm{j}$ & $7.23 \mathrm{k}$ \\
\hline \multirow{2}{*}{\multicolumn{2}{|c|}{$\begin{array}{l}\text { Level of significance } \\
\mathrm{CV}(\%)\end{array}$}} & $* *$ & $* *$ & $* *$ & $* *$ & $* *$ & $* *$ & $* *$ & $* *$ & $* *$ \\
\hline & & 4.68 & 7.60 & 3.72 & 7.40 & 3.64 & 4.12 & 4.25 & 3.68 & 4.40 \\
\hline
\end{tabular}

Means in a column followed by the same letters are not significantly different at $1 \%$ level of probability as per DMRT

** Significant at $1 \%$ level of probability. 
the shortest period with the widest $(50 \times 50 \mathrm{~cm})$ spacing for obtaining $50 \%$ flowering. A significant combined effect of sowing date and plant spacing was also observed on number of fruits per plant. The highest (10.41) number of fruits per plant (4) was found from the plants of 1 October sowing with spacing 50x50 $\mathrm{cm}$ and significantly different form other treatments. The lowest (2.76) number of fruits per plant was noticed in delayed sowing on 30 November with $50 \times 30$ $\mathrm{cm}$ spacing. Fruit size in respect of length and breadth varied significantly due to the combined treatment (Table 3). The longest fruit $(7.16 \mathrm{~cm})$ was produced by the plants sown on 1 September with the widest spacing $(50 \times 50 \mathrm{~cm})$ and $(50 \times$ $40 \mathrm{~cm}$ ), while the shortest length was produced at 30 November sowing with the closest spacing $(50 \times 30 \mathrm{~cm})$. On the other hand, the highest $(6.70 \mathrm{~cm})$ and the lowest $(5.24 \mathrm{~cm})$ fruit breadth were measured from 30 October and 1 September sowings when plants were spaced $50 \times 40 \mathrm{~cm}$. The combined effect of sowing date and spacing had a great influence on individual fruit weight. The maximum individual fruit weight $(51.36 \mathrm{~g})$ was obtained from 15 September sowing with 50 $\times 50 \mathrm{~cm}$ spacing closely followed by $50 \times 40 \mathrm{~cm}$, while the lowest individual fruit weight $(37 \mathrm{~g})$ was obtained from the lowest spacing of $50 \times 30 \mathrm{~cm}$. Diversity was found on yield per plant due to different treatment combinations (Table 3). Sowing on 1 October resulted significantly the highest fruit yield/plant $(388.63 \mathrm{~g})$ with wider spacing $(50 \times 50 \mathrm{~cm})$, while the lowest fruit yield per plant $(108.52 \mathrm{~g})$ was obtained from 30 November sowing with $50 \times 30 \mathrm{~cm}$ spacing. It was evident that the combined effect between sowing time and spacing significantly affected the yield per hectare. The highest fruit yield (19.36 t/ha)

was recorded from the treatment combination of 1 October sowing with $50 \times 30$ $\mathrm{cm}$ spacing, which was statistically different from other treatment combination. The lowest yield $(6.84 \mathrm{t} / \mathrm{ha})$ was recorded from the treatment combinations of 30 November sowing with $50 \times 50 \mathrm{~cm}$ spacing. There was trend to decrease yield/hectare irrespective of spacing after October sowing and also lower on early sowing (1 September). Only breadth of fruit was recorded highest from 1 October sowing with lower spacing. Combined effect of plants $/ \mathrm{m}^{2}$ and other yield parameters revealed higher fruit yield from October sowing with lower spacing $(50 \times 30 \mathrm{~cm})$.

Considering the above findings, 1 October sowing along with lowest spacing $(50 \times 30 \mathrm{~cm})$ appeared to be suitable for higher fruit yield but sweet pepper could be sown up to 30 October with same spacing for reasonable fruit yield. These findings need to be verified at different ABZs of Bangladesh.

\section{References}

AVRDC. 1989. Tomato and Pepper Production in the Tropics. AVRDC, Taiwan. p. 585.

Hasanuzzaman, S. M. 1999. Effect of hormone on yield of Bell pepper (Capsicum annum). M.S. Thesis, Department of Horticulture, Bangladesh Agricultural University, Mymensingh. p.2 
Joshi, M. C. and D.P. Singh, 1975. Chemical composition in Bell pepper. Indian Hort. 20:19-21.

Macrae, R, R. Robinson, and M. Sadler. 1993. Encyclopaedia of Food Science, Food Technology and Nutrition. Academic Press Ltd. pp. 3496-3504.

Manchanda, A.K., S. Bhopal, and B. Singh. 1988. Effect of plant density on growth and fruit yield of Bell pepper (Capsicum annuum L.). Indian J. Agron. 33(4): 445-447.

Maya, P., S. Natarajan and S. Thamburaj. 1997. Effect of spacing. N and P on growth and yield of sweet pepper cv. California Wonder. South Indian Hort. 45: (1-2): 16-18.

Mishriky, J. F. and M. Alphose. 1994. Effect of nitrogen and plant spacing on growth, yield and fruit mineral composition of pepper (Capsician annuum L.). BulL Fac. Agric. Cairo Univ. 45(2):41 3-431.

Ramachandran, S. and K. K. Subbiah.1981. Studies on the effect of plant density and graded levels of nitrogen on yield and yield components of chillies (Capsicum annuum). South Indian Hort. 29(4): 178-181.

Shoemker, J. S. and B. J. E. Teskey, 1955. Practical Horticulture. John Wiley and Sons, Inc. New York. p. 371.

Srivastava, A.K. 1996. Effect of fertilizer levels and plant spacings on flowering, fruit-set and yield of sweet pepper (Capsicum апnиum var. grossum L.) cv. Hybrid Bharat. Advan. Plant Sc. 9(2): 171-1 75.

Verheij, E. W. M. and F. L. J. A. W. Verwer. 1973. Light interception and yield of peppers grown under glass in relation to plant spacing Acta. Hort. 32:149-159.

Viloria, Z.A, R. L. Arteaga and H. A. Radrigues. 1998. Effect of planting distance on bell pepper plant structures. Effect de la distancia de siembra en las estructuras de la planta del pimenton. Agronomia Tropical 48 (A): 413-423 [Cited from HorL Abstr., 69(8): 922, 1999]. 